\title{
"MYELOMA" SERUM ELECTROPHORETIC PATTERNS IN CONDITIONS OTHER THAN MYELOMATOSIS
}

\author{
BY \\ J. A. OWEN,* W. R. PITNEY, AND J. F. O'DEA \\ From the University of Melbourne, Royal Perth Hospital, and Commonwealth Serum Laboratories. \\ Melbourne
}

(RECEIVED FOR PUBLICATION NOVEMBER 27, 1958)

In most patients with myelomatosis, the serum electrophoretic pattern characteristically contains an anomalous component. Occasionally, however, patterns of the "myeloma" type are found in patients in whom the clinical findings and laboratory evidence do not support a diagnosis of myelomatosis.

In this paper, the case histories of 10 such patients are presented and the significance of the findings discussed. Three of these cases have been referred to already (Owen and Rider, 1957).

\section{Methods}

Paper Electrophoresis.-Except in Cases 5 and 7 this was carried out as described by Owen and Rider (1957). Sera from Cases 5 and 7 were examined by a method essentially that described by Flynn and de Mayo (1951). Quantitative results were obtained by elution of dye from stained electrophoretic strips. Total protein was determined by the method of Gornall, Bardawill, and David (1949).

Starch Gel Electrophoresis.-This was carried out as described by Smithies (1955) and was used to estimate (visual comparison with normal patterns) the amount of "normal" $\gamma$-globulin in sera with abnormal components migrating as $\gamma$-globulin.

Ultracentrifugal Analysis-Sera, diluted $1: 4$ in $0.2 \mathrm{M}$ sodium chloride (except in Case 10), were examined in a "spinco" model E ultracentrifuge. In Case 10 the serum was diluted $1: 2$ in $0.15 \mathrm{M}$ sodium chloride. Sedimentation constants were expressed as $S_{20}, w$ values, but were not corrected to zero concentration. For descriptive purposes, the larger (slower) of the two main components of normal serum has been termed "albumin" peak and the smaller (faster) component "globulin" peak.

Precipitin Reactions. -We are indebted to Dr. L. Korngold, Sloan-Kettering Institute, New York, for permission to record his results obtained by a method already described (Korngold and Lipari, 1956).

\footnotetext{
*Present address: St. Vincent's Hospital, Melbourne.
}

\section{Case Histories}

Case 1.-C. M., a man aged 73 years, was admitted to hospital in March, 1956, suffering from melaena. He had a duodenal ulcer demonstrated radiologically; he also suffered from pneumoconiosis. There was no clinical enlargement of liver, spleen, or lymph nodes. Sternal marrow was found to be normal. Radiological examination of the skeleton revealed no abnormality apart from changes suggestive of Paget's disease in the right ilium.

Serum paper electrophoresis revealed an abnormal component migrating between $\beta$ - and $\gamma$-globulin (Fig. 1). Ultracentrifugal analysis of serum showed a normal pattern (Fig. 2a). The results of biochemical and haematological findings are summarized in Table I. There was no proteinuria.

During the next two years the patient was well apart from exertional dyspnoea due, presumably, to the pneumoconiosis. Radiological findings remained unchanged. Re-examination of sternal marrow showed a slight increase in plasma cells, but none were atypical.

In May, 1958, the patient developed obstructive jaundice. At this time an aspiration biopsy of a spinous process revealed normal marrow. At operation, the common bile duct was found to be dilated, due, apparently, to a lesion in the head of the pancreas. A palliative cholecyst-jejunostomy was performed, but the patient developed hepatic failure and died. Necropsy revealed a constriction of the common bile duct as a result of fibrosis in the head of the pancreas consequent on the presence of a peptic ulcer in the second part of the duodenum. Microscopic examination of liver, spleen, lymph gland, and bone marrow showed no abnormality apart from mild lymphocytic infiltration of the portal tracts.

Case 2.-A. W., a man aged 42 years, was admitted to hospital in May, 1955, for investigation of attacks of bronchitis, pneumonia, and pleurisy, which had recurred on 14 occasions during the previous 20 years. No cause was found for the recurrent chest infections. There was no enlargement of liver, spleen, or lymph nodes. Bone marrow examination was normal. Radiographs of the skeleton were 


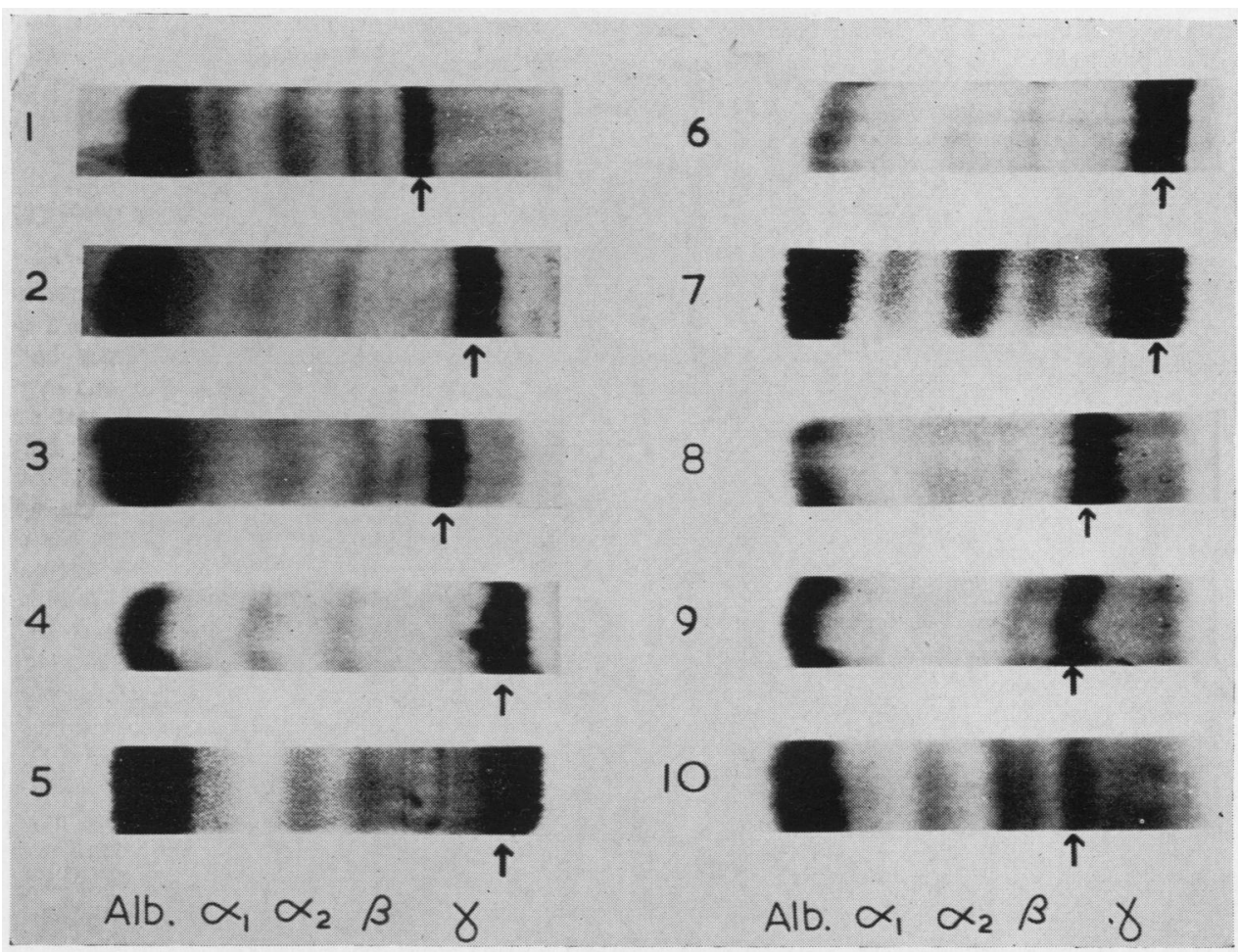

FIG. 1.-Electrophoretic patterns of serum proteins. Arrows indicate the abnormal components.

normal except for an area of translucency in the left ilium, thought to be due to a congenital cyst.

Serum paper electrophoresis revealed the presence of a discrete component migrating as a $\gamma$-globulin (Fig. 1). Starch gel electrophoresis and ultracentrifugal analysis were not carried out, but paper electrophoresis showed little "normal" $\gamma$-globulin. Biochemical and haematological findings are summarized in Table $I$.

The patient has continued to have attacks of chest infection but has not developed any further evidence of multiple myelomatosis.

TABLE I

INITIAL BIOCHEMICAL AND HAEMATOLOGICAL FINDINGS

\begin{tabular}{|c|c|c|c|c|c|c|c|c|c|c|c|c|c|c|c|}
\hline \multirow{2}{*}{ Case } & \multicolumn{6}{|c|}{ Serum Proteins (g. $100 \mathrm{ml}$ ) } & \multirow{2}{*}{$\begin{array}{l}\text { Precipi- } \\
\text { tint } \\
\text { Reaction }\end{array}$} & \multirow{2}{*}{$\begin{array}{c}\mathrm{Hb} \\
(\mathrm{g} . \\
100 \mathrm{ml})\end{array}$} & \multicolumn{5}{|c|}{ Leucocytes $\left(10^{3} \mathrm{c} . \mathrm{mm}.\right)$} & \multirow{2}{*}{$\begin{array}{c}\text { Platelets } \\
\left(10^{3} /\right. \\
\text { c.mm. })\end{array}$} & \multirow{2}{*}{ 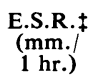 } \\
\hline & Total & Albumin & $a_{1}$ & $\alpha_{2}$ & $\beta$ & $\gamma^{*}$ & & & Total & N. & L. & M. & Others & & \\
\hline $\begin{array}{l}1 \\
2 \\
3 \\
4 \\
5 \\
6 \\
7 \\
8\end{array}$ & \begin{tabular}{r|}
$5 \cdot 7$ \\
$9 \cdot 2$ \\
$6 \cdot 7$ \\
$8 \cdot 8$ \\
$7 \cdot 6$ \\
$11 \cdot 0$ \\
$7 \cdot 3$ \\
$7 \cdot 2$
\end{tabular} & $\begin{array}{l}3 \cdot 1 \\
2 \cdot 7 \\
3 \cdot 2 \\
2 \cdot 7 \\
4 \cdot 0 \\
2 \cdot 5 \\
3 \cdot 1 \\
2 \cdot 3\end{array}$ & $\begin{array}{l}0 \cdot 3 \\
0 \cdot 4 \\
0 \cdot 4 \\
0 \cdot 2 \\
0 \cdot 4 \\
0 \cdot 3 \\
0 \cdot 1 \\
0 \cdot 3\end{array}$ & $\begin{array}{l}0.4 \\
0.5 \\
0.5 \\
0.3 \\
0.5 \\
0.6 \\
0.5 \\
0.5\end{array}$ & $\begin{array}{l}0.4 \\
0.5 \\
0.7 \\
0.3 \\
0.6 \\
0.7 \\
0.7 \\
0.4\end{array}$ & $\begin{array}{l}1 \cdot 5 \\
5 \cdot 3 \\
1 \cdot 9 \\
5 \cdot 3 \\
2 \cdot 0 \\
7 \cdot 1 \\
2 \cdot 8 \\
3 \cdot 7\end{array}$ & $\begin{array}{l}\text { MM I } \\
\text { MM I } \\
\text { MM II } \\
= \\
\overline{-} \\
\text { Macro- }\end{array}$ & $\begin{array}{r}13.0 \\
10.6 \\
11.6 \\
10.1 \\
8.4 \\
3.5 \\
9.1 \\
11.4\end{array}$ & $\begin{array}{l}5 \cdot 3 \\
4 \cdot 8 \\
5 \cdot 5 \\
6 \cdot 4 \\
3 \cdot 1 \\
2 \cdot 5 \\
6 \cdot 6 \\
6 \cdot 8\end{array}$ & $\begin{array}{l}4.4 \\
1.8 \\
3.0 \\
3.8 \\
2.1 \\
1.6 \\
3.5 \\
5.8\end{array}$ & $\begin{array}{l}0.5 \\
2.7 \\
1.6 \\
2.3 \\
0.6 \\
0.7 \\
2.4 \\
0.5\end{array}$ & $\begin{array}{l}0 \cdot 2 \\
0 \cdot 2 \\
0 \cdot 5 \\
0 \cdot 2 \\
0 \cdot 3 \\
0 \cdot 2 \\
0 \cdot 5 \\
0 \cdot 4\end{array}$ & $\begin{array}{l}0 \cdot 2 \\
0 \cdot 2 \\
0 \cdot 4 \\
0 \cdot 1 \\
0 \cdot 1 \\
\cdot \frac{1}{0 \cdot 2} \\
0 \cdot 1\end{array}$ & $\begin{array}{r}- \\
250 \\
330 \\
220 \\
77 \\
400 \\
162\end{array}$ & $\begin{array}{r}15 \\
130 \\
50 \\
138 \\
26 \\
152 \\
126 \\
121\end{array}$ \\
\hline $\begin{array}{r}9 \\
10\end{array}$ & $\begin{array}{l}7 \cdot 5 \\
7 \cdot 8\end{array}$ & $\begin{array}{l}3 \cdot 2 \\
4 \cdot 6\end{array}$ & $\begin{array}{l}0.5 \\
0.2\end{array}$ & $\begin{array}{l}0.2 \\
0.4\end{array}$ & $\begin{array}{l}0.7 \\
1.0\end{array}$ & $\begin{array}{l}2.9 \\
1.5\end{array}$ & $\begin{array}{l}\text { globulin } \\
\text { MM III } \\
\text { Normal }\end{array}$ & $\begin{array}{r}6 \cdot 8 \\
14 \cdot 1\end{array}$ & $19 \cdot 0$ & $17 \cdot 0$ & 1.0 & $1 \cdot 0$ & - & 150 & $\begin{array}{r}150 \\
30\end{array}$ \\
\hline
\end{tabular}

* Including abnormal component. † See Korngold and Lipari (1956). Wintrobe's method was used.

Case 3.-A. C., a man aged 56 years, was admitted to hospital in October, 1957, suffering from pneumonia. He had had three attacks of pneumonia in the previous five months. Six years previously he had fractured his spine in a car accident. There was no clinical enlargement of liver, spleen, or lymph nodes. Bone marrow examination from the sternum revealed $4 \%$ plasma cells showing normal morphology. Radiographs of the skeleton were normal except for some osteoporosis of the vertebral bodies and flattening of the sixth thoracic vertebra, thought to be due to his previous back injury. 
Serum paper electrophoresis showed a discrete component in the $\gamma$-globulin position (Fig. 1). The amount of " normal" $\gamma$-globulin apparent on starch

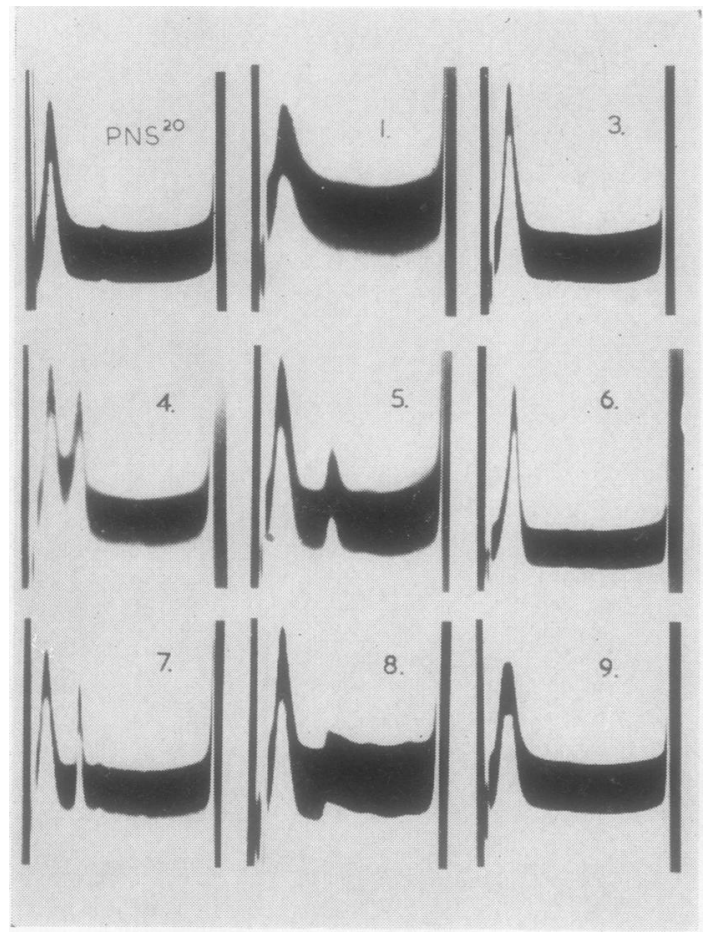

FIG. 2a.-Ultracentrifugal patterns of sera. Patterns are those obtained at $20 \pm 2 \mathrm{~min}$. after reaching constant speed $(60,000$ r.p.m., except in Case 7 where the speed was 50,000 r.p.m.). PNS, pattern of pooled normal serum. Figures indicate case number.
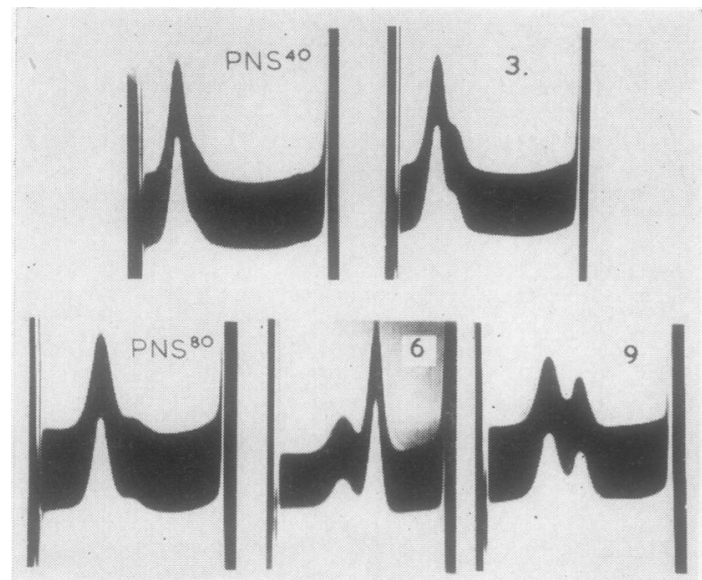

FIG. 2b.-Ultracentrifugal patterns of sera. The patterns were obtained in Case 3, $40 \mathrm{~min}$., and in Cases 6 and 9, $80 \mathrm{~min}$., after reaching constant speed. The patterns of pooled normal serum (PNS) were obtained at corresponding times. gel electrophoresis was not significantly reduced. The ultracentrifugal pattern was normal during the initial part of the run (Fig. 2a); later patterns (Fig. 2b) showed a slight increase in the globulin peak.

The patient was last reassessed in May, 1958. He was well with no anaemia. His serum electrophoretic pattern was as before.

Case 4.-V.T., a woman aged 58 years, has been known to have pulmonary tuberculosis in a quiescent form since 1953. In 1953 a persistently high blood sedimentation rate was noted and she was investigated for possible myelomatosis. This was not substantiated. She was admitted to hospital in July, 1957, suffering from acute meningococcal meningitis. There was no clinical enlargement of liver, spleen, or lymph nodes. $X$-ray examination of the skeleton was normal. Bone marrow aspiration was normal except for a slight increase in plasma cells $(5 \%)$ with normal lymphocytes of $12 \%$. Histological section of marrow fragments showed that the plasma cells tended to occur in clumps.

Serum paper electrophoresis showed a discrete component in the $\gamma$-globulin position (Fig. 1). Starch gel electrophoresis showed that "normal" $\gamma$-globulin was not significantly reduced. The ultracentrifugal pattern (Fig. 2a) revealed an abnormal component with a sedimentation constant of 9.4S. Biochemical and haematological findings are summarized in Table I.

The patient was readmitted to hospital in February, 1958, complaining of backache. $X$-ray examinations disclosed an area of rarefaction with anterior wedging of the twelfth thoracic vertebra and a diffuse, fine mottling in the skull. Marrow aspiration again disclosed only a slight increase in plasma cells, not sufficient to be diagnostic of myelomatosis. Serum proteins were as before. The patient was last reassessed in June, 1958, when she was admitted to hospital suffering from lobar pneumonia. There was now a severe degree of collapse of the seventh, eighth. and twelfth thoracic and the third lumbar vertebrae. A third marrow aspiration again showed a slight increase in plasma cells $(4.5 \%)$ and lymphocytes $(16 \%)$, but the findings were not sufficient to be diagnostic of myelomatosis.

Since this paper was submitted, in December, 1958, the patient has suffered a fatal subarachnoid haemorrhage. At necropsy partial collapse of the lower thoracic vertebral bodies was found. The bony trabeculae were thin and spongy and the marrow spaces were filled with soft, dark red tissue.

Histologically numerous groups of closely packed, small cells possessing a single, eccentrically placed and deeply staining nucleus were seen. The great majority of these resembled plasma cells. These groups occurred in isolated clumps separated by normal bone marrow. In the osseous trabeculae there was evidence of active bone resorption and accompanying fibrosis. 
The appearances were those of multiple myeloma. Failure to obtain a diagnostic aspirate during life could be explained by the patchy distribution of the myeloma cells.

Case 5.-E. H., a woman aged 70 years, was admitted to hospital in December, 1957, suffering from weakness and loss of weight. She was found to be anaemic ; there was moderate enlargement of the liver and spleen and generalized lymphadenopathy. Bone marrow examination from the sternum showed a marked infiltration with lymphocytes. A biopsied lymph node showed the histological picture of lymphosarcoma.

Serum paper electrophoresis revealed an abnormal component with the mobility of $\gamma$-globulin (Fig. 1). Biochemical and haematological findings are summarized in Table $I$. The ultracentrifugal pattern (Fig. 2a) revealed an abnormal component with a sedimentation constant of $15.4 \mathrm{~S}$.

The patient was last reassessed in June, 1958. She felt well and the anaemia had improved following therapy with prednisolone. Lymphadenopathy was still present, but the liver and spleen were reduced in size. Ultracentrifugal analysis of serum showed the abnormal component to be still present but reduced in amount.

Case 6.-D. M., a woman aged 60 years, was admitted to hospital in January, 1958. She had suffered from pneumonia three months previously and had not been well since then. Clinical examination revealed pallor, marked enlargement of both liver and spleen, but no lymphadenopathy. Skeletal radiographs showed punched-out osteolytic lesions in the skull but not elsewhere. Two attempts at bone marrow aspiration were unsuccessful (dry tap). A histological preparation from surgical biopsy of iliac crest was reported as follows:

"The bone marrow is hypercellular due to widespread infiltration with small round cells, mainly lymphocytes, but mixed with these are cells with the appearance of atypical plasma cells. There is plentiful fibroblastic connective tissue. Conclusion: Lymphosarcoma or some closely related condition."

Serum paper electrophoresis revealed an abnormal protein with the electrophoretic mobility of $\gamma$-globulin (Fig. 1). Biochemical and haematological findings are summarized in Table $I$. The ultracentrifugal pattern was normal during the initial part of the run (Fig. 2a); later (Fig. 2b) it was seen that the globulin peak was considerably increased with a marked inversion of the albumin/globulin ratio.

The patient was last reassessed in August, 1958. She has required repeated blood transfusions to maintain an adequate level of haemoglobin in the blood. The clinical findings have not changed.

Case 7.-E. W., a woman aged 75 years, has been described in detail elsewhere (Pitney, O'Sullivan, and Owen, 1958). She suffers from a refractory anaemia of long duration, possibly 15 years. Neither the liver nor spleen are clinically enlarged. One enlarged axillary lymph gland is present. Skeletal radiographs are normal. The bone marrow contains $29 \%$ lymphocytes and $2 \%$ plasma cells.

An abnormal serum protein with the electrophoretic mobility of $\gamma$-globulin (Fig. 1) was discovered in 1955. Starch gel electrophoresis showed a reduction in normal $\gamma$-globulin. The ultracentrifugal pattern (Fig. 2a) revealed an abnormal component with a sedimentation constant of 15.3S. Biochemical and haematological findings are summarized in Table I.

This patient is remarkable in that the anaemia has been corrected on two occasions by prednisolone therapy, even though it is not haemolytic in type. After six months of continuous therapy with prednisolone, the concentration of abnormal protein diminished in the serum. Over the past two years she has suffered from episodes of furunculosis, orbital cellulitis, and acute pyelonephritis. The patient was last reassessed in August, 1958. The haemoglobin value of the blood was satisfactory and the patient felt well. She is taking a maintenance dose of prednisolone.

Case 8.-J. W., a man aged 66 years, was admitted to hospital in September, 1957, suffering from lobar pneumonia. He had had a previous attack of pneumonia five years before but had been well in the meantime. $\mathrm{He}$ failed to respond to therapy with antibiotics and the pneumonic process spread to involve other lobes. He developed anuria and died in uraemia, eight days after admission to hospital. There was no clinical enlargement of liver, spleen, or lymph nodes. Bone marrow examination (sternum) showed an increase in plasma cells $(9 \%)$. These were normal morphologically. Fifteen per cent. of the nucleated cells were lymphocytes. Skeletal radiographs were not taken and necropsy was refused.

Serum paper electrophoresis revealed an abnormal component migrating as a $\gamma$-globulin. Biochemical and haematological findings are summarized in Table I. Ultracentrifugal analysis of serum revealed the presence of three macroglobulin components (Fig. 2a). The most prominent of these had a sedimentation constant of $16.3 \mathrm{~S}$.

Case 9.-S. N., a woman aged 86 years, was admitted to hospital in March, 1957, suffering from auto-immune haemolytic anaemia. Anaemia was severe $(\mathrm{Hb}=6.4 \mathrm{~g}$. $/ 100 \mathrm{ml}$.), with a reticulocyte count of $20 \%$; the direct Coombs test on the red cells was positive and free agglutinin was detected in the serum, active in both saline and albumin at $5^{\circ} \mathrm{C}$., but in albumin only at $37^{\circ} \mathrm{C}$. Results of the $\gamma$-globulin Coombs neutralization test were of the cold agglutinin type.

Serum paper electrophoresis revealed an abnormal protein migrating between $\beta$ - and $\gamma$-globulin (Fig. 1). Biochemical and haematological findings are summarized in Table $I$. There was no proteinuria. Ultracentrifugal analysis revealed a reduced albumin peak with an increased globulin peak. 
The patient did not improve with transfusions or steroid therapy and died five days after admission to hospital. Necropsy failed to reveal a cause for either the auto-immune haemolytic anaemia or the abnormal serum protein. There was neither macroscopic nor microscopic evidence of myelomatosis, the bone marrow showing hyperplasia only when examined microscopically.

Case 10.-A. W., a woman aged 66 , was admitted to hospital in August, 1956, with a swelling on the chest wall attached to a rib. Radiological examination revealed destructive lesions in several ribs. Liver, spleen, and lymph nodes were not enlarged and biopsy of sternal marrow showed no abnormality.

Electrophoresis of serum demonstrated an abnormal component migrating between $\beta$ - and $\gamma$-globulin (Fig. 1). Other biochemical findings are listed in Table I. An ultracentrifugal analysis showed a distinct macroglobulin component, but this was considered to be too small to be of pathological significance.

The histology of a biopsy from the presenting swelling was strongly suggestive of it being a secondary deposit from a thyroid carcinoma. Biopsy of the thyroid gland confirmed malignancy, and on this account an almost complete thyroidectomy was performed. Examination of the operation specimen confirmed the diagnosis. The abnormal serum component was present undiminished one month after the operation. Unfortunately, it has not been possible to follow up this case.

\section{Discussion}

The diversity of findings in the above cases at once suggests that the patients did not all suffer from the same disease. In each case, a diagnosis of myelomatosis was considered initially because of an abnormal discrete component in the serum electrophoretic pattern. In some patients, e.g., Cases 2, 3, and 4, this diagnosis has yet to be excluded. It is well known that myelomatosis may run a protracted course and characteristic skeletal changes may not appear until late, if at all. Thus a patient (T. R.) mentioned briefly in a previous report (Owen and Rider, 1957) did not develop conclusive signs of myelomatosis until two years after an abnormal component was first detected in the serum.

In Case 1, necropsy failed to provide any explanation for the electrophoretic anomaly which appears to have been an incidental finding.

Cases 2 and 3 are both middle-aged men who suffer from repeated lung infections associated with mild anaemia. In Case 2, a lesion in the left ilium remains suspect as a myeloma deposit, although the $x$-ray appearances have not altered over a period of three years. In Case 3, the bone marrow contained $4 \%$ plasma cells which, however, were normal morphologically. In neither case, however, is myelomatosis ruled out.

It is also possible that Case 4 suffers from myelomatosis although the history and findings are unusual. The abnormal serum component (sedimentation constant $=9.5 \mathrm{~S}$ ) has a molecular weight intermediate between that of the usual myeloma protein (sedimentation constant $=6-7 \mathrm{~S}$, Putnam, 1957) and what are termed "macroglobulins" (sedimentation constant $=15-25 \mathrm{~S}$ ). However, relatively high molecular weight proteins have been found occasionally in association with myelomatosis (Waldenström, 1952; Putnam and Udin, 1953; Wanner and Seibenmann, 1957).

The more usual form of Waldenström's macroglobulinaemia (Waldenström, 1944) is well exemplified by Case 5 . Case 6 is, in some ways, similar ; there is enlargement of liver and spleen, with lymphocytic infiltration of the bone marrow. However, there is no enlargement of lymph nodes and the bone marrow shows fibrosis as well as lymphocytic infiltration; further, the abnormal serum protein is not a macroglobulin. Several authors (e.g., Azar, Hill, and Osserman, 1957 ; Mackay, Taft, and Woods, 1957) have reported the association of a myeloma-like serum electrophoretic pattern with malignant lymphoma.

In Cases 7 and 8, the abnormal serum proteins were macroglobulins. In Case 7 , the only abnormal finding, apart from anaemia, was an enlarged axillary gland which has remained stationary in size for two years. Like Cases 2, 3, and 4 , this patient has shown a susceptibility to infection. Case 8 was well before his terminal acute illness and the demonstration of macroglobulin seems to have been an incidental finding. It was particularly unfortunate that necropsy was refused in this case.

The varied clinical findings in Cases 5,7 , and 8 confirm previous conclusions (Martin and Close, 1957) that macroglobulinaemia is probably not associated with any one disease.

No underlying cause was found for the haemolytic anaemia in Case 9. It has been reported, however, that certain patients with idiopathic auto-immune haemolytic anaemia of the cold agglutinin type have an abnormal electrophoretic component migrating as a fast $\gamma$-globulin (Christenson and Dacie, 1957 ; Fudenberg, Barry, and Dameshek, 1958). Case 9 probably falls into this group. In such cases it appears that the abnormal component constitutes the agglutinating substance (Christenson, Dacie, 
and Croucher, 1957). An association of abnormal serum components with haemolytic anaemia has also been noted in patients with lymphoma (Christenson and Dacie, 1957) and chronic lymphatic leukaemia (Craig, Waterhouse, and Young, 1952 ; Buffa and Rappaport, 1957).

In Case 10, the abnormal protein was associated with a carcinoma of the thyroid. Kanzow (1954) and Schaub (1953) have each described single cases of carcinoma of the uterus associated with abnormal serum components (in both cases macroglobulins). However, there was evidence in both cases of an associated lymphoma.

Cases 2 and 3, and to a lesser extent Cases 4 and 7 , showed a susceptibility to infection. Whilst it is tempting to ascribe this to a deficiency of normal $\gamma$-globulin, it must be admitted that in none of these was the reduction in $\gamma$-globulin severe. Hypo- $\gamma$-globulinaemia has frequently been noted in persons with myelomatosis (Adams, Alling, and Lawrence, 1949 ; Rundles, Cooper, and Willett, 1951; Snapper, Turner, and Moscovitz, 1953 ; Waldenström, 1954 ; Zinneman and Hall, 1954 ; Lawson, Stuart, Paull, Phillips, and Phillips, 1955; Porges, 1956; Firkin and Blackburn, 1958), and it has been suggested that the formation of abnormal serum protein competes with the formation of normal $\gamma$-globulin. However, it should be noted that hypo- $\gamma$-globulinaemia has also been reported in reticuloendothelial disease in the absence of abnormal serum components, notably in chronic lymphatic leukaemia (Jim and Reinhard, 1956; Wall, 1956), in malignant lymphoma (Arends, Coonrad, and Rundles, 1954), and in diffuse reticuloendothelial hyperplasia (Citron, 1957).

Korngold and Lipari (1956) have recorded that myeloma sera can be divided into three groups according to the ability of the myeloma protein to react with antiserum prepared against normal $\gamma$-globulin. Sera from four of the six cases tested (Table I) gave reactions similar to those given by myeloma sera. In two of these patients (Cases 1 and 9), however, the results of necropsy examination did not support a diagnosis of myelomatosis, which rather suggests that the precipitin reactions obtained by Korngold and Lipari (1956) are not specific to myelomatosis.

It is inappropriate to consider here at length the pathogenesis of the abnormal serum components. However, there are two points which deserve comment. In several of the cases of the present series (Nos. 1, 2, 3, and 9) there was no evidence of neoplastic disease either of the reticuloendothelial system or of other tissue. The occurrence of abnormal serum proteins in the absence of neoplasia is apparently rare. Apart from cases of cold-agglutinin haemolytic anaemia we have been able to find only a few reports of such cases. These include several well-documented cases of essential cryoglobulinaemia (Hutchinson and Howell, 1953 ; Barnett, Curtain, Hayes, Holden, Pye, and O'Donnell, 1956; Volpé, BruceRobertson, Fletcher, and Charles, 1956), and a few other cases more briefly reported, with diagnoses of hepatitis (Wieme, 1953) and unexplained anaemia (Flynn, 1954 ; Sonnet, Louis, and Heremans, 1955) respectively. Of particular interest is the report (Laurell, Laurell, and Waldenström, 1957) of this anomaly in a blood donor who showed no other physical or laboratory signs of disease.

Secondly, the finding that abnormal electrophoretic components behave, in some instances, as auto-immune agglutinating antibodies is possibly important in any consideration of their pathogenesis. It is possibly also relevant that very high titres of auto-immune complement-fixing antibodies have been found in some sera containing large amounts of macroglobulin (Mackay and Gajdusek, 1958). On the other hand, not every case of auto-immune haemolytic disease has such anomalous protein components. Further, in Hashimoto's disease, which also is characterized by the presence in serum of auto-immune antibodies (Witebsky, Rose, and Shulmann, 1958 ; Roitt, Doniach, Campbell, and Hudson, 1956) the electrophoretic pattern does not reveal anomalous components although the $\gamma$-globulin component is often increased (Luxton and Cooke, 1956; Doniach and Hudson, 1957). This, however, may simply reflect the inadequate resolving powers of prevailing electrophoretic methods.

\section{Summary}

Ten patients are described in whom the serum electrophoretic pattern was of the myeloma type but in whom a diagnosis of myelomatosis was not established. In four patients the abnormal protein was a macroglobulin.

In five patients there was evidence of reticuloendothelial disease whilst one patient suffered from a carcinoma of the thyroid gland. In the other patients there was no evidence of neoplasia.

Four patients showed an increased susceptibility to infection which was possibly related to hypo- $\gamma$-globulinaemia.

It is concluded that whilst discrete abnormal electrophoretic components in serum are most often associated with myelomatosis or lymphoma, they are occasionally present in a variety of other conditions. 
We should like to thank the physicians who have allowed us access to patients in their care and the many others who have helped in this investigation. The technical assistance of Mr. G. S. Wilson, Commonwealth Serum Laboratories, in performing ultracentrifugal measurements is gratefully acknowledged. During part of the investigation, financial support was provided for one of us (J. A. O.) by the National Health and Medical Research Council of Australia, to which we are indebted.

\section{REFERENCES}

Adams, W. S., Alling, E. L., and Lawrence, J. S. (1949). Amer. J. Med., 6, 141 .

Arends, T., Coonrad, E. V., and Rundles, R. W. (1954). Ibid., 16, 833.

Azar, H. A., Hill, W. T., and Osserman, E. F. (1957). Ibid., 23, 239. Barnett, A. J., Curtain, C. C., Hayes, R. A., Holden, H. F., Pye, J., and O'Donnell, I. (1956). Aust. Ann. Med., 5, 177.

Buffa, F., and Rappaport, H. (1957). Amer. J. Med., $22,504$.

Christenson, W. N., and Dacie, J. V. (1957). Brit. J. Haemat., 3, 153.

and Croucher, B. E. E. (1957). Ibid., 3, 262.

Citron, K. M. (1957). Brit. med. J., 1, 1148.

Craig, A. B., Waterhouse, C., and Young, L. E. (1952). Amer. J. Med., 13, 793 .

Doniach, D., and Hudson, R. V. (1957) . Brit. med. J., 1, 672.

Firkin, B. G., and Blackburn, C. R. B. (1958). Quart. J. Med., 27, 187.

Flynn, F. V. (1954). Proc. roy. Soc. Med., 47, 827.

- and Mayo, P. de (1951). Lancet, 2, 235.

Fudenberg, H., Barry, I., and Dameshek, W. (1958). Blood, 13, 201. Gornall, A. G., Bardawill, C. J., and David, M. M. (1949). J. biol. Chem., 177, 751 .

Hutchinson, J. H., and Howell, R. A. (1953). Ann. intern. Med., 39, 350.

Jim, R. T. S., and Reinhard, E. H. (1956). Ibid., 44, 790.
Kanzow, U. (1954). Klin. Wschr., 32, 154.

Korngold, L., and Lipari, R. (1956). Cancer, 9, 262. Korngold, L., and Lipari, R. (1956). Cancer, 9, 262.
Laurell, C. B., Laurell, M., and Waldenström, J. (1957). Amer. J. $\overrightarrow{\vec{F}}$
Med., 22, 24.

Lawson, H. A., Stuart, C. A., Paull, A. M., Phillips, A. M., and Phillips, R. W. (1955). New Engl. J. Med., 252, 13.

Luxton, R. W., and Cooke, R. T. (1956). Lancet, 2, 105.

Mackay, I. R., and Gajdusek, D. C. (1958). Arch. intern. Med., 101, 30.

- Taft, L. I., and Woods, E. F. (1957). Brit. med. J., 1, 561

Martin, N. H., and Close, H. G. (1957). Lancet, 2, 8

Owen, J. A., and Rider, W. D. (1957). J. clin. Path., 10, 373.

Pitney, W. R., O'Sullivan, W. J., and Owen, J. A. (1958). Brit. med. J., $2,1508$.

Porges, R. F. (1956). J. Lab. clin. Med., 47, 960.

Putnam, F. W. (1957). Physiol. Rev., 37, 512.

- and Udin, B. (1953). J. biol. Chem., 202, 727.

Roitt, J. M., Doniach, D., Campbell, P. N., and Hudson, R. v. (1956). Lancet, 2, 820.

Rundles, R. W., Cooper, G. R., and Willett, R. W. (1951). J. clin. Invest., 30, 1125 .

Schaub, F. (1953). Schweiz. med. Wschr., 83, 1256.

Smithies, O. (1955). Biochem. J., 61, 629.

Snapper, I., Turner, L. B., and Moscovitz, H. L. (1953). Multiple 음 Myeloma. Grune and Stratton, New York.

Sonnet, J., Louis, L., and Heremans, J. (1955). Acta haemat. (Basel), $14,193$.

Volpé, R., Bruce-Robertson, A., Fletcher, A. A., and Charles, W. B. (1956). Amer. J. Med., $20,533$.

Waldenström, J. (1944). Acta med. scand., 117, 216.

-(1952). Advanc. intern. Med., 5, 398.

(1954). Acta paediat. (Uppsala), 43, Suppl. 100, p. 87.

Wall, R. L. (1956). Internat. Soc. Haemat. 6th Congr., Boston, p. 288.

Wanner, J., and Siebenmann, R. (1957). Schweiz. med. Wschr., 87, 1243.

Wieme, R. J. (1953). 1 de. Colloqium, Sint-Jans Hospitaal, Brugge, 1953, p. 47.

Witebsky, E., Rose, N. R., and Shulmann, S. (1958). Lancet, 1, 808.

Zinneman, H. H., and Hall, W. H. (1954). Ann. intern. Med., 41, 1152 . 